\title{
UNIVERSITY OF WISCONSIN RADIOCARBON DATES I
}

\section{MARGARET M. BENDER, REID A. BRYSON, and DAVID A. BAERREIS}

\author{
Department of Meteorology, University of Wisconsin, Madison
}

A radiocarbon dating laboratory was installed at the University of Wisconsin in 1963 as part of a program of climatic research in which meteorologists, archaeologists, chemists, botanists, limnologists, geologists, and soil scientists are cooperating.

The $\mathrm{C}^{14}$ dating measurements have been made with a Sharp CDL-14 carbon dating apparatus which includes the Lewis sample converter, based on the method of Fairhall (Fairhall et al., 1961), for the preparation of the methane counting gas. The detector used has a volume of $500 \mathrm{cc}$ and has been operated at pressures varying from $76 \mathrm{~cm}$ to $304 \mathrm{~cm} \mathrm{Hg}$ depending upon sample size. The detector is shielded by a $1 \mathrm{in}$. mercury shroud, anticoincidence guard counter, neutron moderator (saturated boric acid solution) and 4 in. of high purity lead. The background count at $1 \mathrm{std}$ atm, $298^{\circ} \mathrm{K}$, with petroleum methane (Phillips Petroleum Co.) is nominally $2.4 \mathrm{cpm}$.

All background counting rate measurements for the samples reported here have been made with methane synthesized from ancient carbon (anthracite) and the tank hydrogen used in processing the unknown samples and standards in order to minimize the effect of tritium contamination of the hydrogen commercially available.

NBS oxalic acid is used to prepare standard methane; $95 \% \mathrm{~A}_{o x}$, corrected to $298^{\circ} \mathrm{K}$ and $1 \mathrm{std}$ atm is nominally $2.58 \mathrm{cpm}$.

The pretreatment of wood and peat samples follows the usual methods of treatment with $2 \% \mathrm{NaOH}$ and $5 \% \mathrm{HCl}$ after removal of rootlets and other gross foreign matter. Bone samples are treated with $2 \% \mathrm{HCl}$ to remove inorganic carbonates and then washed with distilled water.

The methane samples are stored 2 to 3 weeks before counting. Samples are counted at least 48 hours. The purity of the methane preparations has been checked by mass spectrometer analysis of several samples.

The ages are calculated using 5568 as the half-life of $\mathrm{C}^{14}, 1950$ as the reference year. The standard deviation quoted includes only the $1 \delta$ of the counting statistics of hackground, sample, and standard counts.

\section{ACKNOWLEDGMENTS}

This research is supported by the Atmospheric Sciences Division, National Science Foundation, under grant GP-444. We are indebted to Dr. J. B. Griffin of the University of Michigan for supplying previously-dated samples as a check on our system and to Dr. C. W. Ferguson of the University of Arizona Laboratory of Tree-Ring Research for tree-ring dated woods. 


\section{SAMPLE DESCRIPTIONS}

CHECK SAMPLES

\section{WIS-2.}

M-507, 12,200 \pm 700 в.P., wood with "Jefferson" Mammoth, Jackson County, Michigan (Michigan II).

WIS-3.

$820 \pm 80$

A.D. 1130

Tree-ring dated wood, pinus aristata, A.D. 1141-1145, TRL 62-73, coll. 1962 by C. W. Ferguson, Univ. of Arizona.

WIS-4.

$5290 \pm 120$

3340 в.c.

M-468, $5150 \pm 300$, wood from Michillinda Bog, Lake Michigan (Michigan IV).

WIS-21.

Duplicate sample of WIS-3.

$830 \pm 110$

WIS-33.

Duplicate sample of WIS-3.

A.D. 1120

$760 \pm 100$

I. ARCHAEOLOGIC SAMPLES

A. Mill Creek Series, lowa

Strata cuts of limited dimensions were cut into a series of Mill Creek components in NW Iowa in 1963 under the field supervision of D. R. Henning, Univ. of Wisconsin. Research objectives were to collect stratified samples of cultural and faunal remains as well as soil samples as potential source of pollen to test postulated changes resulting from climatic shift (Ruppé, 1959, p. 11; Griffin, 1961, p. 710-711; 1964, p. 250-251). Radiocarbon samples were intended to establish the duration of Mill Creek occupation in this area and permit precise correlation with climatic events. Earlier Mill Creek dates are limited to: M-1065 (Michigan VII, p. 195) $525 \pm 150$ B.P. (A.D. 1425) for charcoal from a post at the 30 to 32 in. level of the Witrock site (130B4); and M-1096 (Ruppé, letter of Jan. 16, 1963) $850 \pm 150$ B.P. (A.D. 1100) for a sample from the Phipps site (13CK21).

\section{Phipps village site, Iowa 13CK21}

Charcoal from the Phipps site $\left(42^{\circ} 45^{\prime} \mathrm{N}\right.$ Lat, $95^{\circ} 30^{\prime} \mathrm{W}$ Long) coll. in 1963 by D. R. Henning; subm. by D. A. Baerreis.

WIS-26. Phipps site (13CK21)

$600 \pm 100$

Sample from uppermost portion of midden, 8 to $18 \mathrm{in}$. below surface.

\section{WIS-8. Phipps site (13CK21)}

$1000 \pm 70$

Sample taken from an ash and charcoal lens at 48 to 52 in. below surface, Sq. \#3. 


\section{WIS-10. Phipps site (13CK21)}

Sample collected at 48 to $54 \mathrm{in}$. below surface from layer of ash, charcoal, and cultural refuse, Sq. \#4.

\section{WIS-13. Phipps site (13CK21)}

$1140 \pm 100$

54 to $60 \mathrm{in}$. below surface in an ash and charcoal lens, Sq. \#4.

WIS-14. Phipps site (13CK21)

A.D. 1100

$850 \pm 90$

59 to 61 in. below surface from an ash and charcoal lens, Sq. \#4.

\section{WIS-11. Phipps site (13CK21)}

$960 \pm 100$

Sample collected from habitation level at 60 to $64 \mathrm{in}$. below surface in Sq. \#4. Ash and charcoal were mixed with cultural refuse.

\section{WIS-9. Phipps site (13CK21)}

$$
\begin{array}{r}
1020 \pm 80 \\
\text { A.D. } 930
\end{array}
$$

Charcoal from small trash pit (Feature 1) with orifice at lowest level of occupation, 70 in. from surface in Sq. \#3. Pit, with constricted orifice partially sealed with clay, extended into sterile soil.

\section{Witrock site, Iowa 130B4}

Samples from Witrock village site $\left(43^{\circ} 0^{\prime} \mathrm{N}\right.$ Lat, $95^{\circ} 30^{\prime} \mathrm{W}$ Long). Coll. in 1963 by D. R. Henning; subm. by D. A. Baerreis.

\section{WIS-20. Witrock site (130B4)}

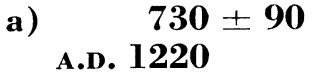

$$
\begin{aligned}
& \text { b) } \quad 700 \pm 110 \\
& \text { A.D. } 1250
\end{aligned}
$$

Charcoal sample from Feature \#4, a cache pit. Pit orifice, sealed with several boulders, was $11 \mathrm{in}$. below surface; date should be regarded as from that level.

\section{WIS-16. Witrock site (130B4)}

$$
690 \pm 90
$$

Charcoal from Feature \#2, a cache pit at depth of $70 \mathrm{in}$. below surface. Pit orifice was $20 \mathrm{in}$. below surface; date should be regarded as from that level.

\section{WIS-34. Witrock site (130B4)}
a) $\quad 370 \pm 100$ A.D. 1580$$
\text { b) } \quad \mathbf{5 5 0} \pm 80
$$

Bison bone from trash pit, Feature \#2 at 52 to 54 in. below surface. This feature originated at depth of 20 in. below surface; date should be regarded as from that level. Comment: second date should be more reliable since a modification of the acid treatment should have guaranteed complete removal of the inorganic carbonate in the second sample. 
WIS-28. Witrock site (130B4)

Charcoal from earlier of two major strata in midden in Sq. \#4, ranging in depth from 23 to 36 in. below surface.

WIS-24. Witrock site (130B4)

$960 \pm 100$

Charcoal collected from trash pit (Feature \#3) at depth of 54 to 60 in. Pit orifice occurred at $24 \mathrm{in}$. below surface.

WIS-39. Witrock site (130B4)

$980 \pm 80$

Bone of large mammal from trash pit at depth of 54 in. (Feature \#3) whose orifice occurred at 24 in. below surface.

\section{Kimball site, Iowa 13PM4}

Samples from Kimball village site $\left(42^{\circ} 30^{\prime} \mathrm{N}\right.$ Lat, $96^{\circ} 30^{\prime} \mathrm{W}$ Long). Coll. in 1963 by D. R. Henning; subm. by D. A. Baerreis.

WIS-23. Kimball site (13PM4)

$640 \pm 80$

Charred popcorn (id. by H. C. Cutler, Missouri Bot. Garden, St. Louis) collected from a trash pit, Feature \#4, Sq. \#3. Pit orifice was 18 in. below surface.

WIS-22. Kimball site (13PM4)

$940 \pm 60$

Charcoal from Sq. \#2, 30 to $36 \mathrm{in}$. below surface. It constitutes the uppermost charcoal sample obtainable.

WIS-31. Kimball site (13PM4)
a) $640 \pm 90$ A.D. 1310
b) $\quad 850 \pm 100$ A.D. 1100

Charred wood from an occupation level, 36 to 42 in. below surface.

\section{WIS-32. Kimball site (13PM4)}

$720 \pm 100$ surface.

Charred wood from lowest occupation level at depth of 84 to $90 \mathrm{in}$. below

\section{WIS-19. Kimball site (13PM4)}
a) $750 \pm 90$ A.D. 1200
b) $\quad 950 \pm 100$ A.D. 1000

Charcoal collected at 84 to $90 \mathrm{in}$. below surface in Sq. \#2. It probably represents the heginning of site occupation.

WIS-36. Kimball site (13PM4)

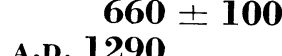

Bone of small mammal from lowest occupation level in site, 84 to $90 \mathrm{in}$. below surface. 


\section{WIS-30. Waterman Crossing site, Iowa (130B3)}

Charcoal from Waterman Crossing site $\left(43^{\circ} 0^{\prime} \mathrm{N}\right.$ Lat, $95^{\circ} 30^{\prime} \mathrm{W}$ Long), collected at depth of 18 to 20 in. below surface. Coll. 1963 by D. R. Henning; subm. by D. A. Baerreis.

General Comment: dates from Kimball site are most erratic of the deep midden sites. Since these middens, however, contain many large storage pits, some areas are likely to contain charcoal and other debris disturbed by this activity and brought by mechanical action to inappropriate levels. A.D. 1000 to A.D. 1300 is regarded as reasonable range for site. The smaller, shallow Waterman Crossing site falls within same period. The Phipps site probably was occupied slightly earlier (A.D. 900?) and perhaps continued to a later time (A.D. 1400?) since our topmost sample did not date actual surface of the midden accumulation. The Witrock site seems first to have been occupied at about same time as Kimball site. It also provides the most dates in the series.

\section{Sipolite series, Oaxaca}

$$
\text { B. Mexico }
$$

Two samples obtained from site of Sipolite $\left(15^{\circ} 39^{\prime} \mathrm{N}\right.$ Lat, $96^{\circ} 31^{\prime} \mathrm{W}$ Long), near Puerto Angel, Oaxaca, Mexico. Coll. 1962 and subm. by D. Brockington, San Diego State College.

\section{WIS-40. Sipolite midden}

Carbonized wood from Pit 14 in midden deposit at depth of 1.75 to $2.00 \mathrm{~m}$ below surface. Comment: since entire midden is prehistoric, recent date is not in agreement with archaeological material.

\section{WIS-41. Sipolite midden}

$3750 \pm 100$ 1800 в.с.

Carbonized copal (a natural resin from tropical trees) from Pit 12 in midden deposit at depth of 1.75 to $2.00 \mathrm{~m}$. Comment: date should have been equivalent to WIS-40 but is earlier than anticipated.

\section{Oklahoma}

\section{WIS-42. Creek Site (D1-41), Oklahoma}

Charcoal from Lillie Creek (D1-41) site $\left(36^{\circ} 30^{\prime} \mathrm{N}\right.$ Lat, $94^{\circ} 59^{\prime} \mathrm{W}$ Long) in Delaware County, Oklahoma. Wood was 24 to 28 in. below surface in sq. NE 9:10 from a burned structure on an early stage in the construction of a flat-topped platform mound. Site is placed in Spiro Focus, Gibson Aspect. Coll. 1939 and subm. by D. A. Baerreis. Comment: date is appropriate for Gibson Aspect and in agreement with WIS-44, WIS-46 and WIS-49.

WIS-43. Gertrude Bowman Site (Lf-66), Oklahoma

$560 \pm 80$ A.D. 1390

Charcoal from Test Pit 1, House 1, of Unit III of the Gertrude Bowman (Lf-66) site $\left(35^{\circ} 14^{\prime} \mathrm{N}\right.$ Lat, $94^{\circ} 40^{\prime} \mathrm{W}$ Long). Coll. 1940 by K. G. Orr; subm. by D. A. Baerreis. Site is component of Fort Coffee Focus described by 
Orr (1946). House plan, a rectangular, two-center-post structure, is illustrated by Wallace (1962, Pl. 8). Comment: date is appropriate as marking onset of Fulton Aspect in Spiro area.

\section{WIS-44. Hughes site (Ms-5), Oklahoma $\quad 730 \pm 80$}

Charcoal from rafters of House 1 of Hughes (Ms-5) site $\left(35^{\circ} 45^{\prime} \mathrm{N}\right.$ Lat, $95^{\circ} 20^{\prime} \mathrm{W}$ Long). Coll. 1939 by L. E. Howard; subm. by D. A. Baerreis. Desig. nated a "Late Spiro Component" by Orr (1946, p. 251), floor plan of the square, four center-post house is illustrated by Wallace (1962, Pl. 3). Comment: two additional houses from site have been dated: House 3, M-817 (Michigan V, p. 37) as $1050 \pm 150$ B.P. (900 A.D.) ; House 8, 0-594 (Bell, 1958) as $875 \pm 100$ (1075 A.D.). The spread of dates seems rather wide to represent occupation period of the village but some of the charcoal specimens may be derived from the inner rings of large center posts so that A.D. 1100 to 1200 seems a more reasonable span for the occupation. Dates and typological characteristics of the houses are more appropriate for a Gibson Aspect assignment than for a "Late Spiro Component" as suggested by Orr.

\section{Reed site series, Oklahoma}

Charcoal from Reed site (D1-1) (36 $39^{\prime} \mathrm{N}$ Lat, $94^{\circ} 47^{\prime} \mathrm{W}$ Long), derived from superimposed patterns of three houses located beneath a flat-topped platform mound. Houses are square with a four center-post pattern and entrance passageways opening to the $\mathrm{S}$ and SE. Since many charcoal specimens were saturated with paraffin in the field as a preservative, one portion of sample (WIS-46) was extracted with petroleum ether before $\mathrm{NaOH}-\mathrm{HCl}$ treatment in order to compare the date with a sample (WIS-49) treated as usual.

\section{WIS-46. Petroleum ether extracted}

\section{WIS-49. Normal treatment}

Comment: virtual identity of dates rules out paraffin contamination as explanation of erratic character of some Oklahoma dates, at least so far as this specimen is concerned. These dates are actually in close agreement with another date for Reed site: M-819 (Michigan V, p. 38), $1100 \pm 150$ B.P. 1850 A.D.). Dates should mark the initial phase of occupation at this component of Spiro Focus, Gibson Aspect.

$$
\text { 1I. GEOLOGIC SAMPLES }
$$

\section{Muskeg series}

\section{A. Manitoba}

Two samples were dated, primarily to obtain muskeg growth rates. One was from a quite fresh unhumified string bog near Lynn Lake, Manitoba (WIS-25) and suggests that the 4 to $5 \mathrm{~m}$ typical depth of string bogs in the area represent perhaps $2000 \mathrm{yr}$ of growth if some allowance is made for compression in lower part of bog. The other sample, from base of the upland muskeg near Root Lake, Manitoba gives similar total age of the deposit 
(WIS-1) but a growth rate in $\mathrm{cm} /$ century about one-seventh as great. These rather recent dates for initiation of the muskeg growth are rather surprising.

\section{WIS-1. Root Lake, Manitoba}

Basal upland muskeg at depth of $109 \mathrm{~cm}$ over gray clay, $20 \mathrm{mi} \mathrm{N}$ The Pas, Manitoba $\left(54^{\circ} 07^{\prime} \mathrm{N} \mathrm{Lat}, 101^{\circ} 17^{\prime} \mathrm{W}\right.$ Long). Coll. 1963 by R. Knollenberg, Univ. of Wisconsin, Madison; subm. by R. A. Bryson.

\section{WIS-25. Lynn Lake, Manitoba}

$$
\begin{array}{r}
340 \\
\text { A.D. } 1610
\end{array}
$$

Sphagnum from bottom of a string bog, Zed Lake Road, 15 mi from Lynn Lake, Manitoba $\left(56^{\circ} 58^{\prime} \mathrm{N}\right.$ Lat, $101^{\circ} 16^{\prime} \mathrm{W}$ Long), from depth of $111 \mathrm{~cm}$, $30 \mathrm{~m}$ from the edge. Coll. 1963 by R. Knollenberg; subm. by R. A. Bryson.

\section{B. Northwest Territories}

\section{Southwest Keewatin series}

A series of buried charcoal layers overlying podzol soils was found along a transect running from inside the boreal forest on Ennadai Lake $\left(60^{\circ} 42^{\prime} \mathrm{N}\right.$ Lat, $101^{\circ} 46^{\prime} \mathrm{W}$ Long) to full tundra on Dubawnt Lake $\left(63^{\circ} \mathrm{N}\right.$ Lat, $100^{\circ}$ $50^{\prime} \mathrm{W}$ Long). Dates for these charcoal layers show that the forest border has extended $\mathrm{N}$ of its present position at least twice in post-glacial time, once prior to about 3500 B.P. and again prior to about 900 B.P. Dates for charcoal from exposures with unequivocal stratigraphy quite consistently cluster about these dates (WIS-5, 6, 7, 12, 17, 18, 27) but a few samples which are from questionable contexts due to severe cryoturbation or poor burial give dates between these two forest epochs (WIS-15 and 29).

The stratigraphy in "Knoh A" (WIS-37), a pillar left by deflation of the surrounding area, is similar to that at Ennadai Aeradio about $1000 \mathrm{~m}$ away (WIS-5) but the date is not consistent. The reason is not known. For a discussion of these forest beds see Bryson et al. (1965).

Similar exposures of charcoal and podzol $\mathrm{N}$ of the present tree-line are found $\mathrm{W}$ and $\mathrm{E}$ of this transect on Artillery Lake $\left(63^{\circ} 20^{\prime} \mathrm{N}\right.$ Lat, $107^{\circ} 35^{\prime}$ W Long) and Henik Lake $\left(61^{\circ} 40^{\prime} \mathrm{N}\right.$ Lat, $97^{\circ} 30^{\prime}$ W Long).

WIS-5. Ennadai Aeradio Esker, N.W.T.

$$
880 \pm 180
$$

Spruce charcoal from charcoal bed at lake shore at Ennadai Aeradio Station $\left(61^{\circ} 8^{\prime} \mathrm{N}\right.$ Lat, $100^{\circ} 53^{\prime} \mathrm{W}$ Long $)$. Occurs over podzol soil but under a wind-blown sand layer and tundra vegetation. Coll. 1963 and subm. by R. A. Bryson.

\section{WIS-37. Ennadai Aeradio Esker, N.W.T.}

$$
\begin{array}{r}
1590 \\
\text { A.D. } 360
\end{array}
$$

Charcoal from 3 to $5 \mathrm{~cm}$ charcoal and sand layer, "Knob A," 1/2 mi E of Aeradio Station $\left(61^{\circ} 8^{\prime} \mathrm{N}\right.$ Lat, $100^{\circ} 52^{\prime} \mathrm{W}$ Long $)$, under $50 \mathrm{~cm}$ wind-blown sand but lying over well-developed paleosol on parent esker material. Coll. 1963 and subm. by R. A. Bryson. 
WIS-6. Birch Bay, Ennadai Lake, N.W.T.

Buried charcoal (forest fire) layer over fossil podzol on shore of Birch Bay, Ennadai Lake, ca. $2 \mathrm{mi}$ from inlet of Kazan River on $\mathrm{W}$ slope of esker $\left(60^{\circ} 43^{\prime} \mathrm{N}\right.$ Lat, $101^{\circ} 49^{\prime} \mathrm{W}$ Long). Sample was covered with 20 to $35 \mathrm{~cm}$ of acolian sand. Coll. 1963 and subm. by R. A. Bryson.

WIS-7. Ennadai Lake, N.W.T.

$4000 \pm 160$ 2050 в.c.

Charcoal bed (forest fire) 75 to $80 \mathrm{~cm}$ below surface of muskeg on shore of Ennadai Lake, $\mathrm{N}$ of Ennadai Aeradio Station $\left(61^{\circ} 20^{\prime} \mathrm{N}\right.$ Lat, $100^{\circ} 49^{\prime} \mathrm{W}$ Long). Coll. 1963 and subm. by R. A. Bryson.

\section{WIS-12. Slow River Blowout, Dubawnt Lake, $\quad 3430 \pm 110$ N.W.T. \\ 1480 в.C.}

Charred wood and forest duff (from forest fire) under $8 \mathrm{~cm}$ of acolian sand and over podzol soil apparently at $\mathrm{N}$ edge of fossil podzol distribution. Sample from Slow River Blowout was taken from left bank of an estuary $1 \mathrm{mi}$ above its mouth at $\mathrm{E}$ shore of Dubawnt Lake $\left(63^{\circ} 02^{\prime} \mathrm{N}\right.$ Lat, $100^{\circ} 48^{\prime} \mathrm{W}$ Long). Coll. 1963 by W. N. Irving, Natl. Mus., Ottawa, Canada; subm. by R. A. Bryson.

\section{WIS-15. Sterns Lake, N.W.T.}

$$
\begin{array}{r}
1450 \\
\text { A.D. } 500
\end{array}
$$

Comminuted charcoal in sand over podzol but under tundra on esker slope near Sterns Lake, SE corner $\left(61^{\circ} 13^{\prime} \mathrm{N}\right.$ Lat, $100^{\circ} 24^{\prime} \mathrm{W}$ Long). Distorted by frost action and may be contaminated. Coll. 1963 and subm. by R. A. Bryson.

WIS-17. Dimma Lake, N.W.T.

Buried forest fire charcoal over podzol soil near Dimma Lake $\left(61^{\circ} 33^{\prime} \mathrm{N}\right.$ Lat, $100^{\circ} 38^{\prime} \mathrm{W}$ Long), from $1 \mathrm{ft}$ below tundra vegetation. Coll. 1963 by J. A. Larsen, Univ. of Wisconsin, Madison; subm. by R. A. Bryson. Probably dates same forest epoch as WIS-5 and WIS-6.

\section{WIS-18. Caribou Point, Ennadai Lake, N.W.T $\quad 3550 \pm 120$}

1600 в.C.

Charcoal from lower of two buried forest layers over podzols at Caribou Point, E side of Ennadai Lake $\left(60^{\circ} 49^{\prime} \mathrm{N}\right.$ Lat, $10^{\circ} 17^{\prime} \mathrm{W}$ Long). Coll. 1963 by W. N. Irving; subm. by R. A. Bryson.

WIS-27. Caribou Point, Ennadai Lake, N.W.T $1090 \pm 130$

Charcoal from upper of two buried forest layers (see WIS-18). Coll. 1963 by W. N. Irving; subm. by R. A. Bryson. 
$100^{\circ} 48^{\prime}$ W Long), Ennadai Lake, N.W.T. Postdates artefacts similar to material attributed to Thule culture. Disturbed by frost action. Coll. by W. N. Irving; subm. by R. A. Bryson.

\section{Wisconsin}

\section{WIS-38. Steve Creek, Taylor County, Wisconsin}

Beaver cuttings excavated from marsh $8 \mathrm{ft}$ below surface, $7 \mathrm{ft}$ below present bottom of Steve Creek $\left(45^{\circ} 22^{\prime} \mathrm{N}\right.$ Lat, $90^{\circ} 36^{\prime} \mathrm{W}$ Long), in a 3 to 4 in. layer of silt material above a layer of sand and gravel, below two peat layers separated by $2.5 \mathrm{ft}$ of blue clay, upper peat layer $1 \frac{1}{2} \mathrm{ft}$, lower $21 / 4 \mathrm{ft}$ thick. Coll. 1963 and sulm. by B. L. Dahlberg, Wisconsin Conservation Dept.. Spooner, Wisconsin.

\section{WIS-48. Scuppernong River Basin, Jefferson $\quad 12,800 \pm 220$ County, Wisconsin \\ 10,850 в.c.}

Spruce wood from basal peat (lower 6 in.) sampled at drainage ditch section through a peat mound, Scuppernong River basin $\left(42^{\circ} 54^{\prime} \mathrm{N}\right.$ Lat, $88^{\circ}$ $36^{\prime}$ W Long), Jefferson County, Wisconsin. Wood occurred as horizontal roots and branches lying in the peat, $3 \mathrm{ft}$ thick at drainage ditch exposure, which was over buried humic-gley paleosol. Coll. 1963 and subm. by F. D. Hole, Soils Dept., Univ. of Wisconsin, Madison. Comment (F. D. Hole) : it seems most likely that the wood represents vegetative growth after melting of glacial ice from the Scuppernong-Bark River glacio-lacustrine basin in SE Jefferson County. There is remote possibility that wood represents forest growth on debris on glacier which was gradually lowered as ice melted.

\section{REFERENCES}

Date lists:

$\begin{array}{ll}\text { Michigan II } & \text { Crane and Griffin, 1958 } \\ \text { Michigan IV } & \text { Crane and Griffin, 1959 } \\ \text { Michigan V } & \text { Crane and Griffin, 1960 } \\ \text { Michigan VII } & \text { Crane and Griffin, 1962 }\end{array}$

Michigan VII Crane and Griffin, 1962

Bell, Robert E., 1958, Radiocarbon dates from Oklahoma: Oklahoma Anthropol. Soc. Newsletter, v. 7 , no. 3 , p. 3 .

Bryson, Reid, A.. Irving. William N., and Larsen, James A., 1965, Radiocarbon and soils evidence of former forest in the southern Canadian tundra: Science, v. 147, p. 46-48.

Crane, H. R., and Griffin, J. B., 1958, University of Michigan radiocarbon dates II: Science. v. 127 , p. $1098-1105$.

1959, University of Michigan radiocarbon dates IV: Am. Jour. Sci. Radioc. Supp., v. 1, p. 173-198.

1960, University of Michigan radiocarbon dates V: Am. Jour. Sci., Radioc. Supp., v. 2, p. 31-48.

p. 183-203. rhall, A. W., Schell, W. R., and Takashima, Y., 1961, Apparatus for methane synthesis for radiocarbon dating: Rev. Sci. Instruments, v. 32, no. 3, p. 323-325.

Griffin, James B., 1961, Some correlations of climatic and cultural change in eastern North American prehistory: Annals New York Acad. Sci., v. 95, art. 1, p. 710-717.

1964, The northeast woodlands area in Prehistoric man in the New World, J. Jennings and E. Norbeck, eds.: Chicago, Univ. Chicago Press, p. 223-258.

Orr, Kenneth, G., 1946, The archaeological situation at Spiro, Oklahoma, a preliminary report: Am. Antiquity, v. 11, no. 4, p. 228-256.

Ruppé, Reynold, J., 1959, Archeology at SUI: Jour. of Iowa Archaeol. Soc., v. 9, no. 1,

p. 9-11.
Wallace, Benny, J., 1962. Prehistoric house patterns of Oklahoma: Bull. of Oklahoma Anthropol. Soc., v. 10, p. 27-68. 